\title{
Unique retroinnominate course of the left brachiocephalic vein
}

\author{
Niraj Nirmal Pandey, Arun Sharma, Priya Jagia
}

Department of Cardiovascular Radiology and Endovascular Interventions, All India Institute of Medical Sciences, New Delhi, India

\section{Correspondence to Dr Priya Jagia, drpjagia@yahoo.com}

Accepted 11 October 2018
Check for updates

(c) BMJ Publishing Group Limited 2018. No commercial re-use. See rights and permissions. Published by BMJ.

\begin{tabular}{|l|}
\hline To cite: Pandey NN, \\
Sharma A, Jagia P. BMJ Case \\
Rep Published Online First: \\
[please include Day Month \\
Year]. doi:10.1136/bcr-2018- \\
227558 \\
\hline
\end{tabular}

\section{DESCRIPTION}

A 4-year-old girl diagnosed with tetralogy of Fallot on transthoracic echocardiogram, was referred for a CT angiography (CTA) for preoperative anatomical assessment of the primary cardiac defect and associated cardiovascular anomalies. Review of CTA images revealed a unique anomalous course of the left brachiocephalic vein (*) where it was seen crossing the midline above the arch, anterior to the left common carotid artery (LCCA) and left subclavian artery (LSCA) but coursing posterior to the innominate artery, before joining the right brachiocephalic vein (RBCV) to form the right superior vena cava (RSVC) (figure 1A-D).

Unlike the anomalous retroaortic brachiocephalic vein which has a sub-aortic course and crosses the midline below the arch, the left brachiocephalic vein in the index case traverses above the arch and in front of the LCCA and LSCA; however; it curves posteriorly to cross posterior to the innominate
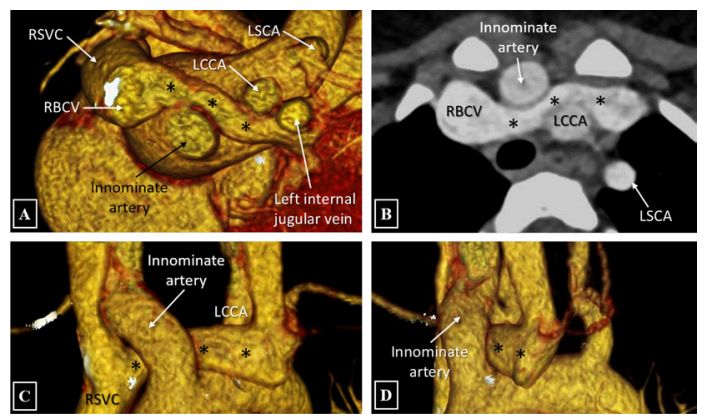

Figure 1 Volume rendered and axial maximum intensity projection images of $\mathrm{CT}$ angiography (A-D) depicts the left brachiocephalic vein $\left(^{*}\right)$ traversing anterior to the left subclavian artery and left common carotid artery and posterior to the innominate artery, before joining the right brachiocephalic vein. LCCA, left common carotid artery; LSCA, left subclavian artery; $\mathrm{RBCV}$, right brachiocephalic vein; RSVC, right superior vena cava. artery before joining the RBCV to form the RSVC. Although the anomaly itself, in isolation, is not clinically significant and can be considered a normal variant, it becomes crucial to identify such aberrant courses prior to performing invasive procedures such as transvenous electrode/pacemaker placement and central venous pressure line insertion. This anomaly can result in technical difficulties in the said procedures, especially when a left-arm approach is adopted. ${ }^{1}$

\section{Learning points}

Retroinnominate brachiocephalic vein, after crossing anterior to the left subclavian and left common carotid artery, curves posteriorly to cross posterior to the innominate artery before joining the right brachiocephalic vein to form the superior vena cava.

- In isolation, retroinnominate brachiocephalic vein is not clinically significant and can be considered a normal variant.

- It can result in technical difficulties in transvenous electrode/pacemaker placement and central venous pressure line insertion, especially when a left-arm approach is adopted.

Contributors NNP, AS and PJ have participated sufficiently in the conception of the idea, development of the intellectual content, design, writing and final approval of the manuscript.

Funding The authors have not declared a specific grant for this research from any funding agency in the public, commercial or not-for-profit sectors.

Competing interests None declared.

Patient consent Parental/guardian consent obtained.

Provenance and peer review Not commissioned; externally peer reviewed.

\section{REFERENCE}

1 Chen SJ, Liu KL, Chen HY, et al. Anomalous brachiocephalic vein: CT, embryology, and clinical implications. AJR Am J Roentgenol 2005; 184:1235-40. 
Copyright 2018 BMJ Publishing Group. All rights reserved. For permission to reuse any of this content visit http://group.bmj.com/group/rights-licensing/permissions.

BMJ Case Report Fellows may re-use this article for personal use and teaching without any further permission.

Become a Fellow of BMJ Case Reports today and you can:

- Submit as many cases as you like

- Enjoy fast sympathetic peer review and rapid publication of accepted articles

Access all the published articles

- Re-use any of the published material for personal use and teaching without further permission

For information on Institutional Fellowships contact consortiasales@bmjgroup.com

Visit casereports.bmj.com for more articles like this and to become a Fellow 